\title{
Duration of Intra-Operative Stimulation as a Predictor of Success of Spinal Cord Stimulation for Chronic Pain Syndromes
}

\author{
Kronik Ağrı Sendromlarında Omurilik Stimülasyon Başarısının Bir \\ Göstergesi Olarak Intraoperatif Stimülasyonun Süresi
}

Hosam AL-JEHANI ${ }^{1,2}$, Wissam ESSAWI ${ }^{1,2}$, Line JACQUES ${ }^{1}$

${ }^{1}$ Montreal Neurological Institute and Hospital, Department of Neurology and Neurosurgery, Montreal, Canada

${ }^{2}$ King Fahad University Hospital, University of Dammam, Department of Neurosurgery, Alkbobar, Saudi Arabia

Correspondence address: Hosam AL-JEHANI / E-mail: hosam.aljehani@gmail.com

\begin{abstract}
AIM: Electrical stimulation of the dorsal column of the spinal cord stands out as a major method of neuromodulation. Its popularity stems from the long lasting support to the "gate theory" in which electrical stimulation of the gate prevents passage of nociceptive impulses and reduces pain sensation. There is little known about the effect of the duration of intraoperative stimulation (IOS) trial on the success of the spinal cord stimulation trial.

MATERIAL and METHODS: We present our result on 58 patients with spinal cord stimulation implantation and their IOS trials and short-term follow up.

RESULTS: The major finding of this study is that the longer the IOS trial, the higher the chances for failure of SCS. Our study also suggests that tripolar spinal cord stimulation leads present a more reliable option for long-term success of the spinal cord stimulation (SCS).

CONCLUSION: The duration of IOS seems to influence the result of the initial trial of SCS. IOS should be between 30-60 minutes to optimize the placement of the lead for better correlation with the SCS trial.

KEYWORDS: Dorsal column, Electrical stimulation, Failed back surgery, Gate control theory, Spinal cord

ÖZ

AMAÇ: Omurilik dorsal kolon stimülasyonu, nöromodülasyonun önemli metotlarından biridir. Bu metodun popülaritesi “kapı kontrol teorisini” uzun süreden beri desteklemesinden ileri gelmektedir. Bu teoriye göre "kapının" elektrik stimülasyonu nosiseptif uyarıları önleyerek ağrı duyusunu azaltır. Omurga stimülasyonun başarısında intraoperatif stimülasyonun (IOS) süresi hakkında çok az bilgi mevcuttur.

YÖNTEM ve GEREÇLER: Omurilik stimülasyon implantasyonu takılan 58 hastanın iOS süresi ve kısa-süreli takip sonuçları sunulmuştur.

BULGULAR: Bu çalışmanın en önemli bulgusu iOS süresi uzadıkça omurga stimülasyonunun başarılı olma şansının azalmasıdır. Çalışmamız aynı zamanda, tri-polar omurilik stimülasyonunun uzun süreli başarıda daha güvenilir bir seçenek olduğunu göstermiştir.

SONUÇ: IOS süresi omurilik stimülasyon sonuçları üzerinde etkili gibi görünmektedir. Stimülasyon başlığının uygun yerinin belirlenmesi için IOS süresi 30 ile 60 dakika arasında olmalıdır.
\end{abstract}

ANAHTAR SÖZCÜKLER: Dorsal kolon, Elektrik stimülasyonu, Başarısız bel cerrahisi, Kapı control teorisi, Spinal kord

\section{INTRODUCTION}

Neuromodulation can be defined as the electrical or chemical modification of the central or peripheral nervous system, which changes the actual or perceived neurotransmission and response to a stimulus or condition. Since its invention, electrical stimulation of the dorsal column of the spinal cord stands out as a major method of neuromodulation, especially for chronic pain conditions (6). Its popularity stems from the long lasting support to the "gate theory" in which electrical stimulation of the gate prevents passage of nociceptive impulses and reduces pain sensation (5). Current applications of spinal cord stimulation are numerous and include a myriad of painful condition, vascular ischemia, and cognitive recovery in vegetative states (4). The mechanism by which spinal cord stimulation (SCS) achieves its effects is not well defined. Postulated mechanisms of action include activation of neurotransmitter release, down regulation of sympathetic activity, and modification of the expression of a variety of neurotrophic factors with cellular effect $(1,3)$.

The trial of spinal cord stimulation allows the patient to get acquainted with the "response to be" using SCS. The duration of the spinal cord stimulation trial is variable across centers 
of practice, with implantations undertaken the same day implantation to up to one month have been reported. Variability of the initial response assessment is an important confounding factor to implantation decisions that could potentially affect long-term outcome of the spinal cord stimulation.

There is little known about the effect of the duration of intraoperative stimulation trial on the success of the spinal cord stimulation trial. Our objective was to analyze the effect of the duration of IOS on the success of the trial of stimulation and elucidate potential effectors that could influence patient selection for SCS.

\section{MATERIAL and METHODS}

We conducted a retrospective analysis of prospectively collected data including all new spinal cord stimulation procedures, weather temporary or permanent, from June 2007 to June 2009. We excluded patients with pain syndromes other than failed back surgery syndrome (FBSS) and chronic regional pain syndrome (CRPS) to homogenize our cohort. A total of 58 cases were reviewed. One patient was excluded because the initial follow up was conducted in another hospital and information was not accessible.

All implantations were done by the senior author (L.J.) and all patients were evaluated and followed up following a standardized protocol at the pain clinic at the Montreal Neurological Institute and Hospital. After receiving the proper education and obtaining an informed consent, patients were submitted to the implantation of the surgical lead. Patients were placed in a prone position and received light sedation and local anesthesia to facilitate laminotomy and placement of the lead, after which the patients are allowed to be fully awake for the subsequent stimulation. The intraoperative stimulation was conducted through an externalized extension wire connected to a handheld modulator. The proper position of the lead was ensured by proper coverage of the painful area with paresthesia. The subcutaneous tissue and skin were closed in separate layers and a bulky adhesive dressing was applied ensuring air seal around the incision and the extension wire. The patients were discharged either the same day or the next day and were kept on oral antibiotics till the permanent implantation was undertaken. On the day of the temporary implantation, the patients were instructed to start the stimulation using a hand held programmer and evaluate their response. The majority of the trials were between 24 to 48 hours but some patients extended up to 72 hours. We proposed a "trial scale" that assessed the response to the trial of stimulation based on the degree of pain reduction and paresthesia coverage (Table I). If the trial is successful, patients were submitted to permanent implantation under general anesthesia, placed in a right lateral decubitus to facilitate the implantation and tunneling of the extension kit as well as the creation of the abdominal pocket to accommodate the internal pulse generator. The subcutaneous tissue and skin for both incisions were closed in two layers and the patients received oral antibiotics upon discharge for 3 days. The pain medication regimen is not adjusted till the first postoperative visit in the pain clinic usually within 2-3 weeks.

The duration of IOS trial was classified into 3 groups: less than 30 minutes, between 30 to 60 minutes, and more than 60 minutes. The polarity used for the surgical paddle-type leads were either bipolar configuration with 8 contacts or tripolar with 16 independent contacts. The statistical analysis was performed using the application Graphpad prism version 4.0 for windows.

\section{RESULTS}

A total of 57 patients were included in this review. Of those, 6 patients $(10.5 \%)$ were decided to have unsatisfactory trial of stimulation and were explanted. Fifty-one patients had permanent implantation. Of these 51 patients (80\%) had FBSS and the remainder were patients with CRPS.

Patients who had IOS trial of less than 30 minutes constituted $21.05 \%$ of the cohort, $57.89 \%$ between $30-60$ minutes, and $21.05 \%$ more than 60 minutes. A significant difference was observed for the excellent to good trial outcome with 30-60 minutes IOS $(p=0.061)$. All trial failures occurred in patients with IOS trials more than 60 minutes. $(p=0.0035$, Pearson $r=$ 8.55). The primary diagnosis and target cord segment (FBSS vs. CRPS, Axial back pain vs. leg pain vs. upper extremity in CRPS) did not influence the duration of the IOS.

Bipolar leads were used in 36 patients (63.1\%) and tripolar leads were used in 21 patients (36.9\%). Of bipolar leads IOS trials, 33\% were less than 30 minutes, 55\% between $30-60$ minutes, and $11 \%$ more than 60 minutes. For the tripolar leads the distribution across IOS durations was $10 \%, 76 \%$, and $14 \%$ respectively. Two failures were seen in bipolar leads and 4 were seen in tripolar leads. Together, these results suggest the propensity for the IOS using the tripolar leads to be more difficult and time consuming but on the other hand more

Table I: "Proposed" Trial Scale

\begin{tabular}{l|l} 
Response & Criteria \\
\hline Excellent & $>75 \%$ reduction of pain and optimal coverage \\
Good & $65-75 \%$ reduction of pain, and optimal coverage \\
Satisfactory & $50-65 \%$ reduction of pain and optimal coverage \\
\hline Suboptimal & $<50 \%$ reduction of pain or incomplete coverage of painful area \\
\hline Failure & $<50 \%$ reduction of pain and incomplete coverage of painful area \\
& Team's deferral to proceed to phase II
\end{tabular}


reliable for patient selection for permanent implantation and successful long term treatment outcome.

\section{DISCUSSION}

The success of the spinal cord stimulation for pain syndromes is affected by several factors. The challenges includes patient factors (age, level of education, degree of expectations... etc), complexity of pain distribution (axial vs. appendicular) and primary diagnosis (FBSS, CRPS, CAD, PVD, etc). Procedural factors that affect stimulation trials include positioning discomfort, cooperation, and distraction. Programming parameters for a stimulation trial are not well characterized and there is a lack of uniform algorithms for intraoperative stimulation.

A major source of variability among centers of practice is the variable trial time for confident perception. This might affect the acquaintance of the patient with the desired stimulation. This could lead to suboptimal results if the implantation is not verified and the stimulation is tested for an adequate time period. Our practice is that of a short stimulation trial with the majority of patients being permanently implanted permanently within 48 hours. The benefit of such practice is the reduction of infection risk and the hardware morbidity.

Our study shows that the duration of the intraoperative stimulation trial could be a significant factor in predicting the success of the trials; leading to permanent implantations of spinal cord stimulation. The longer IOS (>60 minutes) correlated with SCS trial failure and removal of the device. The more interesting finding of our cohort study is the finding of the effect of the type of lead on stimulation trial. With similar insertion technique, we found that the tripolar leads are more complex to program in the intraoperative setting when compared with bipolar lead types. This translated into more trial failures in the tripolar lead type stimulation trials. The tripolar type lead had more excellent-to-good response rate in the long term follow up of our patients. This justifies the use of tripolar leads in complex pain syndromes, even if there is a tendency to failed trials, with the more robust result of SCS using the tripolar leads.

Spinal cord stimulation trial is intended for the patients to get acquainted with the "response to be expected" when using SCS. Variability of the initial response could be confounding to implantation decisions and its effect on longterm outcome. The duration of the trial is variable by center of practice. It ranges from 24 hours to 4 weeks. There is no uniform algorithm for the optimal programming for patients during the stimulation. There is little known about the effect of IOS on the outcome of SCS. One study addressed the most appropriate parameters for the trial period not the IOS (2).

One of the limitations of our studies include the limited diagnoses that could influence the generalizability of the response to IOS and SCS trial in different application of SCS the other is the somewhat limited numbers with the inherent weakness of any retrospective analysis of data. To our knowledge, this is the first study to demonstrate the effect of the duration of the IOS on SCS trial outcome and correlating that to long-term outcome. With longer IOS trial, the trend should incorporate longer SCS trials than usual, to give patients enough time before concluding that they failed SCS trials and being explanted prematurely.

\section{CONCLUSION}

The duration of IOS seems to influence the result of the initial trial of SCS. IOS should be between 30-60 minutes to optimize the placement of the lead for better correlation with the SCS trial. The use of tripolar leads seems to increase the reliability of IOS and SCS trial for long-term effect

\section{ACKNOWLEDGMENTS}

We thank Elizabeth Cote, the head nurse at Montreal Neurological Institute/Hospital Operating Room for her help with surgical data collection and Claire Nehme, a clinical nurse specialist in the pain clinic at Montreal Neurological Institute/ Hospital for her help with clinical data collection, and to Dr. Taner Tanriverdi from Istanbul University for his help with the preparation of this manuscript.

\section{REFERENCES}

1. Barolat G: Spinal cord stimulation for chronic pain management. Arch Med Res 31: 258-262, 2000

2. Gordon A, Zou S, Kim Y, Gharibo C: Challenges to setting spinal cord stimulator parameters during intraoperative testing: Factors affecting coverage of low back and leg pain. Neuromodulation 10:133-141, 2007

3. Holsheimer $\mathrm{H}$ : Which neuronal elements are activated directly by spinal cord stimulation. Neuromodulation 5: 25-31, 2002

4. Lee AW, Pilitsis JG: Spinal cord stimulation: Indications and outcomes. Neurosurg Focus 21: E3, 2006

5. Melzack R, Wall PD: Pain mechanisms: A new theory. Science 150: 971-979, 1965

6. Shealy CN, Mortimer JT, Reswick JB: Electrical inhibition of pain by stimulation of the dorsal columns: Preliminary clinical report. Anesth Analg 46: 489-491, 1967 